\title{
Deficient Feminine Nature Theory: Functional Ability Analysis in North-Western Society of Pakistan
}

\author{
Mamoon Khan Khattak \\ Department of Social Work \& Sociology \\ Kohat University of Science \& Technology (KUST) \\ Khanzadi Fatima Khattak \\ Faculty of Sciences \\ Abdul Wali Khan University \\ Zubaida Khatoon Khattak \\ Department of Economics \\ University of Peshawar
}

\begin{abstract}
This research task is based on application analysis of the Marxist's "The Deficient Feminine Nature Theory (DFNT)" which explains the nature of people's attitude especially of males and this attitude's underlying causes towards females. This theory provides and furthers the explanation of the phenomenon that how the women are unjustly exploited on the basis of this assumption that they are deficient. The core objective of the research has been to analyze the functional-ability of the said theory in the context of the society of the Islamic Republic of Pakistan, a traditional and cultural values preserving society within the world. A number of 600 male respondents were interviewed of married status who were within the age group ranging from 25 years to 55 years; this category of the respondents were selected with the assumption that they may have a significant influential status over females within the community. The North-Western province i.e. Khyber Pakhtunkhwa (KP) was selected at random for samples' selection.
\end{abstract}

Key Words: Female, Feminine, Gender, Society, The Deficient Feminine Nature Theory

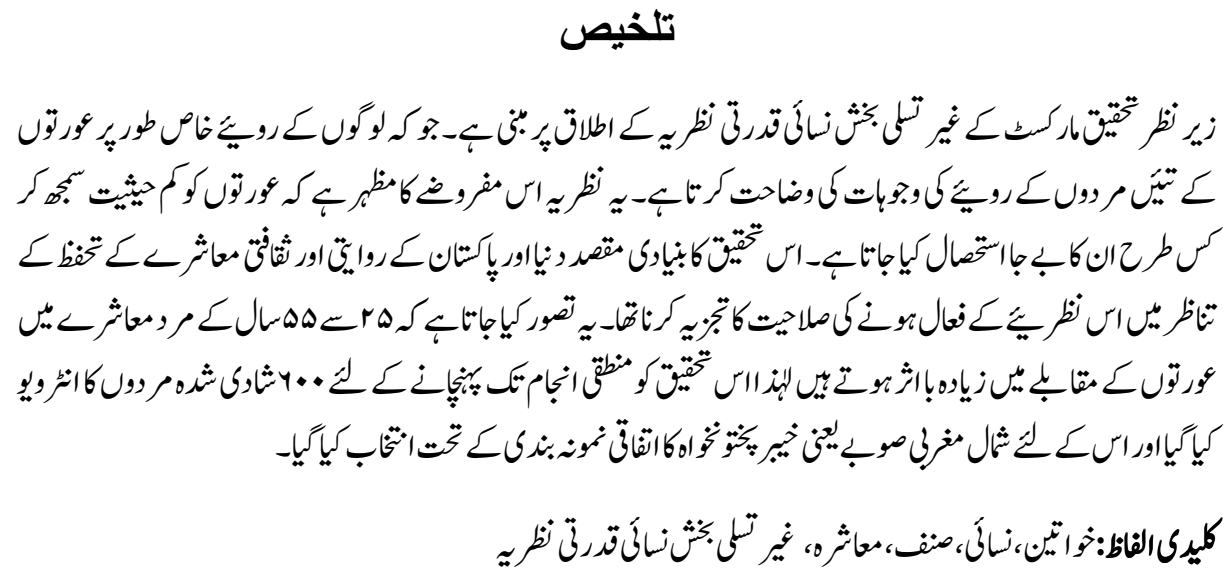




\section{Introduction}

The society on the bases of various reasons and justifications, do not want to have the females with an empowered status. The society wants its values preservation, hence the empowerment of females is deviance from the core social values. The masses have been reluctant to alter the stereotypes existing within the society that have hurdled the females' empowerment. The socio-cultural criterions vary up to a greater extent regarding consideration of what is feminine. The gender-stereotypes affect the influence prevalent feminine-occupations, consequential in micro-aggression directed toward females who deviate from the gender roles set traditionally (Derald, 2010). These stereotypical roles include that women do possess a caring innate nature, do have skills of the domesticchores, have superior manual skill as compared to males, are comparatively honest than the men, and the women do have an attractive physical posture. Beckford (2009) says that although greater number of females now do have a high-status employments, hence they are still salaried less than the males and they are less expected to get the senior positions.

The community has a fear that if females go out of home for availing the opportunities of empowerment then their honour will be at risk, i.e. if they go for acquiring education and or availing employment opportunities. In this way, the females remain lesser developed and the people perceive females as deficient in comparison with males in terms of psychosocial characteristics. Women are not considered as potential for leadership (Chin, 2007). The findings show the leadership based on the feminine-style is associated with pattern which concentrate on helping and cooperating; this gain advantage over the leadership of masculine-style that is associated with concentration over the control and tasks. The female leaders are often projected by the mass media utilizing the characteristics linked with femininity, for example emotions (Klenke, 2004).

Majority of the masses are contented with absence of females' empowerment. The deficiency in females' empowerment is called as unavoidable by the society. Hence this law is termed as "a natural law of the society" in order to discourage the sympathetic feelings for the unlucky females. The people do not desire to alter the patterns and values that their elders were practicing. The status and roles in society assigned to females are restricted i.e. the females were having lesser economic and employment opportunities therefore the society consider that the women may not to be given education, and hence they are disempowered. It is argued that the main sex-characteristics of male and female, say for example the ability of bearing children, established a historic sexual seclusion of labour while the gender based stereotypes developed culturally to continue this very division (Worell, 2001). 


\section{Research Methodology}

A total 600 respondents including 300 from rural areas and 300 from urban areas were selected and then interviewed within the North-Western province of Pakistan i.e. Khyber Pakhtunkhwa (KP). For the convenience, greater level of coverage, representation, validity of the research findings and results, the all four administrative divisions of Khyber Pakhtunkhwa namely Southern Region, Northern Region, Central Region and Northwestern Region were included in the research study. The size of sample has been selected on the basis of proportion from all regions of its population while using different sampling techniques of non-probability sampling method. Through stratified random sampling technique, out of each four selected districts, one rural and one urban area has been selected; detail is in Table-1.

Table: 1

Region Wise Proportionate Sampling in Khyber Pakhtunkhwa

\begin{tabular}{|c|c|c|c|c|}
\hline \multirow{2}{*}{$\begin{array}{l}\text { Region of } \\
\text { Province } \\
\text { (District) }\end{array}$} & \multirow[t]{2}{*}{$\begin{array}{l}\text { Population in } \\
\text { Millions (\%) }\end{array}$} & \multicolumn{3}{|c|}{$\begin{array}{l}\text { No. of Respondents selected population proportion } \\
\text { wise }\end{array}$} \\
\hline & & $\begin{array}{c}\text { Total } \\
(\%)\end{array}$ & Rural (\%) [Location] & $\begin{array}{l}\text { Urban (\%) } \\
\text { [Location] }\end{array}$ \\
\hline $\begin{array}{l}\text { Southern } \\
\text { (Karak) }\end{array}$ & $3.57(20.12)$ & $\begin{array}{c}122 \\
(20.3) \\
\end{array}$ & $\begin{array}{c}61(10.15) \\
{[\text { SaratKhel] }}\end{array}$ & $\begin{array}{c}61 \text { (10.15) [Tappi } \\
\text { Kanda] }\end{array}$ \\
\hline $\begin{array}{l}\text { Central } \\
\text { (Charsada) }\end{array}$ & $6.40(36.08)$ & $\begin{array}{l}216 \\
(36)\end{array}$ & $\begin{array}{c}108 \\
(18)[\text { BatgramChuraKhel }\end{array}$ & $\begin{array}{c}108(18) \\
\text { [GhundaKarkana] }\end{array}$ \\
\hline $\begin{array}{l}\text { North- } \\
\text { Western } \\
\text { (Dir Lower) }\end{array}$ & $4.26(24.01)$ & $\begin{array}{l}144 \\
(24)\end{array}$ & $\begin{array}{c}72(12) \\
\text { [LarchamManial] }\end{array}$ & 72 (12) [Balambat] \\
\hline $\begin{array}{l}\text { Northern } \\
\text { (Kohistan) }\end{array}$ & $3.51(19.79)$ & $\begin{array}{c}118 \\
(19.7)\end{array}$ & 59 (9.85) [Baikuz] & $59(9.85)$ [Dassu] \\
\hline $\begin{array}{l}\text { KP Twenty } \\
\text { Five Districts }\end{array}$ & 17.74(100) & $\begin{array}{c}600 \\
(100)\end{array}$ & $300(50)$ & $300(50)$ \\
\hline
\end{tabular}

Source: "Population Census Report 1998", 2000, Population Census OrganizationStatistics Division, Islamabad, Pakistan.

The KP has a patriarchal type of society, where males have more powerful roles, which ultimately affect the lives of females. Hence the interview was made of the male respondents who were married and were within the age group of 25-55 years on the basis of this logical assumption that this age group has comparatively influential role in their families and society, over their females; then these respondents were selected accidentally at random during interview process in the respective areas of the society. 
The collected data was analyzed through standard statistical applications; statistical averages were used in percentage form and the significance of the data was checked while using statistical tests. The Chi Square Test of Significance was applied to the responses made by the rural area respondents, of the responses made by the urban area respondents and to the sum of the responses- made by rural area respondents and of urban area respondents (these all three categories were analyzed separately, independent of each other). The Z Test of Significance was applied for the comparison of the responses made by the rural area respondents with that of the responses made by the urban area respondents.

\section{Discussion on: "Marxist's- The Deficient Feminine Nature Theory"}

The Marxist's gender in-equality theory titled as "The Deficient Feminine Nature Theory" has provided explanation of the phenomenon that why the discrimination prevails, whereever it is, in world society regarding females. The Marxist's says that during the course of time the exploiting classes do have propagated ideology of the "Deficient Feminine Nature". Through this pseudo-theory it was envisioned to uphold and validate the act of submission of females and that till now females pass through in communities where ever this exploitation remains prevalent. The femininity is also named as womanliness, or womanhood, is a collection of traits, behaviours, status and roles that are generally linked with women. The femininity is prepared up of both the socially-defined and biologicallycreated factors in society (Wijngaard, 1997; Martin \& Finn 2010; Kalbfleisch\& Cody, 1995; Dunphy, 2000). Therefore, it is made as distinct from the modest definition of biological sex of female as female, male, and the transgender individuals may all exhibit the feminine-traits. On the basis of this discrimination the females' equality of rights is discarded in almost every walk of life i.e. social, educational, religious, political and economic etc.

People consider the females of inferior mental maturity (Peru People's Movement Report, 1996). The behavioural traits that are often considered feminine, do include the trait of gentleness, trait of empathy, and the trait of sensitivity (Worell, 2001), hence the traits that are linked with the femininity most often vary subject to locale and context, and that may also include a variety of socio-cultural factors (Witt, 2010). The females are abstained from accessing the political process and are urged to restrain within their homes. The females' tasks are considered mostly to tend babies, the different works of the home and the varying tasks of the motherhood. To a degree the women are enforced to select to live-up to the vision regarding their education, development and socialization or to live-up to the community's implications of being becoming a wife or a mother. Societies give females a secondary-status, hence they are given respect and they do have rights that have made them associate to their male spouses. In this context the females are forced to develop their lives to a significant degree submitted, although protected by the 
laws. Despite all the liberating laws, the female continues to be overburdened, oppressed and humiliated to some extent by the unskilled tasks of domestic nature that makes her nearly a nurse or a cook. The cultural element in community of perceiving females' psychosocial deficient is of undue advantage for males, which has resulted in giving disadvantages to females. The feminine condition has become further intolerant with the time went on and actually it has confirmed the economic, political, social, and ideological subjugation of females (Weiner, 1982).

To quote the feminist philosophers for example the Judith Butler and Simon de Beauvoir (Wijngaard, 1997) oppose that the masculinity and femininity are shaped by recurrent performances of the gender; resultantly these presentations produce, recur, and express the traditional classes of gender and/or of sex (Butler, 1990). The Role Congruity Theory suggests that the individuals incline to see nonconformities from probable gender-roles negatively; it is occasionally used to elucidate why individuals do have a propensity to assess behaviour that fulfills the instructions of a leader role with fewer favour when it is decreed by a female (Eagly \& Karau, 2002; Rudman \& Peter, 2001; Heilman, 2001; Heilman et al., 2004; Schein, 2001).Leadership is linked to masculinity in the Western cultures (Chin, 2007). The complementary to femininity is the masculinity. The essential features of femininity are universally not indistinguishable, while some outlines do exist. The concept feminine is meant as that of female sex, biologically female; having the qualities associated with a woman or the female gender, which includes suitable characteristics of a woman. The characteristics such as empathy, gentleness, caring, sensitivity, compassion, sweetness, nurturance, tolerance, succorance and deference are behaviours often considered as the feminine (Worell, 2001). This self-adopted discernment of the society has enabled its male members to confiscate unjustified advantages over their females. They have endeavored to attain undue females' subservience, educational advantages, socio-economic advantages, religious and political advantages etc., which has pushed the females at a disadvantageous status in the society. The society thinks that the females should simply stick to prevailing feminine stereotyped roles in society and they should merely serve males (Bem, 1972).

In view of the Halpern (2000), both the socialization versus inborn features play a significant role regarding gender identity and gender-specific behaviour, hence the comparative significance of each still necessarily be explored. In year 2005, the scientific research exploring sex and psychology exhibited that gender-expectations and gender stereotype risk affect behaviour, and an individual's gender-identity may evolve as early as at his/her three years of age (Gallagher \& Kaufman, 2005). The society preserves its values under practice without taking significant consideration of the fact that whether these values are conducive for development of the individuals living in it (society)? The society has a degree of stagnancy in its thought and practice, it lesser welcomes change and development process. The social values of the society are not much conducive for the 
promotion and development of females. It rarely permits the emergence of supportive social values that may uplift females in their social and overall development. Rather the societal practices forces females to be in a fixed magnitude for a meager growth and development. The description of femininity is the outcome of how females necessarily behave in order to uphold a social system based on patriarchy (Kloppenborg \& Hanegraaff, 1995; Pateman, 1988).

The society socializes females with predefined and pre-existent stereotyped roles in the society. The females' traditional role in the society is that they live a life of meager status with a submissive dealing and relationship with males. The society thinks that females cannot make themselves mature at par with males; cannot understand complexities of life and cannot develop ability to perceive well about social phenomena. It thinks that females possess immature thinking, which can never be ripened. The society is convinced for not educating, developing and socializing their females because of the fear that this process of uplift will make females discontented with their current status which will possibly annoy males. They fear that through education the females will be empowered and will remain no more submissive to males. Discrimination in female's access to opportunities of development persists in many areas, owing to customary attitudes, early marriages and lack of adequate accessible education and training facilities. Due to this reason, the uplift of females is thought in the society to upset the social equilibrium of the era. The society has reservations that females would cease to fulfill their conventional roles, if they are developed. It is thought that females cannot fill their preordained place in society if they are wasting their time in gaining knowledge. These ideas of society seem unreasonable from present century point of view but are still being practiced (Hassan, 1996).

\section{Primary Data's Analysis}

The primary data was collected from male respondents of the target area through face to face interviews. The data in the Table-2 shows that from overall $600(100 \%)$ respondents, $83.7 \%$ (with $\mathrm{P}-\mathrm{Value}=0$ ) respondents were of the view that females are deficient in comparison with males regarding psycho-social characteristics and $16.3 \%$ of respondents were of the opposite view. Regarding comparison of the rural and urban respondents $(50 \%$ respondents in each subdivision) data shows that $40.5 \%$ (with $\mathrm{P}-\mathrm{Value}=0$ ) rural while $43.2 \%$ (with P-Value=0) urban respondents (with comparison significance P-Value=.077) were of the view that the females are deficient in comparison with males regarding psycho-social characteristics. A number of $20.2 \%$ respondents were of the view that because of the reason that the females are deficient psychosocially, they should be given lesser chances of psychosocial development. Regarding comparison of the rural and urban respondents, $11 \%$ (with $\mathrm{P}-\mathrm{Value}=0$ ) rural while $9.2 \%$ (with $\mathrm{P}-\mathrm{Value}=0$ ) urban respondents (with comparison significance $\mathrm{P}-\mathrm{Value}=.263$ ) were of the view that because 
of the reason the females are deficient psychosocially as compared to males, they should be given lesser chances of psychosocial development.

The Table- 2 further shows that among the respondents who opined that the females are psychosocially deficient in comparison with males regarding psycho-social characteristics, $83 \%$ (with P-Value=0) respondents were of the view that due to deficient feminine psychosocial nature the females cannot develop sociability skills well, regarding comparison of the rural and urban respondents (50\% respondents in each subdivision) $40.2 \%$ (with $\mathrm{P}-$ Value $=0$ ) rural while $42.8 \%$ (with $\mathrm{P}-$ Value $=0$ ) urban respondents (with comparison significance $\mathrm{P}-\mathrm{Value}=.082$ ) were of the view that due to deficient feminine psychosocial nature females cannot develop sociability skills well. The dominant majority of the society was of the view that due to deficient feminine psychosocial nature females cannot develop certain personality characteristics well. The females cannot develop sociability skills well. They think that the females cannot establish and maintain good social relations. They cannot meet, greet and entertain guests independently. They can hardly arrange social events. They can hardly make judgments regarding differentiating good people from bad people.

A number of $81.7 \%$ (with P-Value=0) respondents have had the view that because of the deficient feminine psychosocial nature the females cannot become strong psychologically, regarding comparison of the rural and urban respondents 39\% (with P-Value $=0$ ) rural while $42.7 \%$ (with $\mathrm{P}-\mathrm{Value}=0$ ) urban respondents (with comparison significance PValue $=.020$ ) have given their view that due to deficient feminine psychosocial nature females cannot attain strong psychological state. The society perceived that the women cannot have strong observation, memory, perceptive skills and cognitive skills. While keeping this all in mind and not giving the opportunity of development to females is not fair. A number of $82.3 \%$ (with $\mathrm{P}-\mathrm{Value}=0$ ) respondents were of the view that due to deficient feminine psychosocial nature the females cannot become as strong as men emotionally, regarding comparison of the rural and urban respondents, $40 \%$ (with PValue=0) rural while $42.3 \%$ (with P-Value=0) urban respondents (with comparison significance $\mathrm{P}-\mathrm{Value}=.136$ ) were of the view that due to deficient feminine psychosocial nature females cannot become as strong as men emotionally. The females are experiences as of fearing of social situations. When they encounter a complex social situation, they get depressed, start weeping, take tension become upset, become stressed and even loss conscious. They do trust earlier, get angry earlier and can be deceived earlier.

\section{Conclusions}

It is very clear that every human being is created and given birth by the will of Allah Almighty, with abundant potential capabilities, hence with certain limitations, restrictions and socio-cultural conditions as well. The concept of deficient females' psychosocial 
state is wrongly interpreted. The society's perception regarding females- in the context of the "Deficient Feminine Nature Theory" is functional in society Islamic Republic of Pakistan, which has given females a great setback in terms of attainment of socioeconomic privileges. It has served the purpose of justifying the males' oppression and discrimination against females. Due to this phenomenon females are rarely allowed to be developed and educated, because this will surely give them fair strength and empowerment. The perception of females as psychosocially deficient beings should be eliminated so that the males may discontinue taking undue advantage of it. By doing so, the females' sufferings would be stopped, which will save them from unfavourable outcomes of educational, cultural, economic and social disadvantages. Females should be made free from these unfavourable societal stereotypes, which give them meager status in the society. It should be made clear to the society that if females are backward in any sphere, it is only because that they are given fewer chances of education, socialization and development. However the human being has a broader range and capacity of development, which is only possible through its utilization. The females should be given fullest chances of psychosocial development as much as is humanly possible. Through this, females will become capable of attaining their rights of social, psychological, emotional and economic spheres of their lives. The females of Pakistan's society do also have enormous energies which should be promoted and utilized for their own welfare, particularly, and for the welfare of the society, generally.

\section{References}

Beckford, Martin (August 11, 2009). "More British Women in 'High Status' Professions than Men”, The Daily Telegraph, UK.

Bem, D. (1972). "Self Perception Theory", Academic Press, New York, USA, p.62.

Butler, J. (1990). “Gender Trouble: Feminism and the Subversion of Identity”, New York; Routledge.

Chin, Jean Lau (2007). "Women and Leadership: Transforming Visions and Diverse Voices” Wiley-Blackwell.

Derald, Wing Sue (2010).“Microaggression in Everyday Life: Race, Gender, and Sexual Orientation”, John Wiley and Sons, New Jersey, p.72.

Dunphy, Richard (2000). "Sexual Politics: an Introduction", Edinburgh University Press.

Eagly, Alice H., Karau, Steven J. (2002). "Role Congruity Theory of Prejudice toward Female Leaders”, Psychological Review, vol.109:3, pp. 573-598. 
Gallagher, Ann M., Kaufman, James C. (2005). “Gender Differences in Mathematics: an Integrative Psychological Approach”, Cambridge University Press.

Halpern, Diane F. (2000). "Sex Differences in Cognitive Abilities”, Psychology Press, New York.

Hassan, Iftikhar N. (1996). "Psychology of Woman", Instant Printing System, Islamabad, Pakistan.

Heilman, Madeline E. (2001). "Description and Prescription: How Gender Stereotypes Prevent Women's Ascent Up the Organizational Ladde”, Journal of Social Issues, vol.57: 4, pp. 657-674.

Heilman, Madeline E., Aaron S. Wallen, Daniella Fuchs, and Melinda M. Tamkins (2004). "Penalities for Success: Reactions to Women Who Succeed at Male Gender-Typed Tasks", Journal of Applied Psychology, vol.89: 3, pp. 416-427.

Kalbfleisch, Pamela J., Cody, Michael J. (1995). “Gender, Power, and Communication in Human Relationships", Psychology Press.

Klenke, Karin (2004). “Women and Leadership: A Contextual Perspective”, Springer Publishing Company.

Kloppenborg, Ria, Hanegraaff, Wouter J. (1995). "Female Stereotypes in Religious Traditions", BRILL.

Martin, Hale, Finn, Stephen Edward (2010). "Masculinityand Femininity in the MMPI-2 and MMPI-A", University of Minnesota Press.

Pateman, Carole (1988). “The Sexual Contract”, Stanford: Stanford University Press, p.207.

Peru People's Movement (MPP) Report 1996 (Translation), previously published by Central Committee, Communist Party of Peru (PCP), 1976. http://www.blythe.org /peru-pcp/docs_en/feminist.html retrieved dated 14th February 2013.

Rudman, Laurie A. \& Peter Glick (2001). "Prescriptive Gender Stereotypes and Backlash Toward Agentic Women", Journal of Social Issues, vol.57:4, pp.743-762.

Schein, Virginia E. (2001). "A Global Look at Psychological Barriers to Women's Progress in Management”, Journal of Social Issues, vol.57:4, pp. 675-688.

Weiner, B (1982). “Emotional Consequences of Casual Attributes”, Hillsdale Press, J.J. Erlbaum, p.53. 
58 Deficient Feminine Nature Theory: Functional Ability Analysis in North-Western Society of Pakistan

Wijngaard, Marianne van den (1997)."Reinventing the Sexes: the Biomedical Construction of Femininity and Masculinity. Race, Gender, and Science”, Indiana University Press.

Witt, edited by Charlotte (2010). "Feminist Metaphysics: Explorations in the Ontology of Sex, Gender and Identity”, Dordrecht: Springer, p.77.

Worell, Judith (2001) "Encyclopedia of Women and Gender: Sex Similarities and Differences and the Impact of Society on Gender", vol. 1, Elsevier.

Table: 2

Respondents' Opinion Regarding Status of Females' Deficient Psychosocial Characteristics, Provision of Chances of Psychosocial Development to Females and Females Ability-Status to Develop Well Certain Personality Characteristics

\begin{tabular}{|c|c|c|c|c|c|c|c|c|c|c|c|c|c|c|c|c|c|c|c|c|c|}
\hline \multirow{3}{*}{ 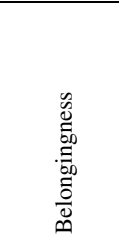 } & \multirow{3}{*}{ 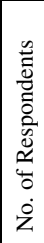 } & \multirow{2}{*}{\multicolumn{4}{|c|}{$\begin{array}{l}\text { Females are deficient as } \\
\text { compared to males in } \\
\text { terms of } \\
\text { psychosocial } \\
\text { characteristics }\end{array}$}} & \multirow{2}{*}{\multicolumn{4}{|c|}{$\begin{array}{l}\text { If females are deficient, } \\
\text { then they should } \\
\text { be given lesser chances } \\
\text { of psychosocial } \\
\text { development }\end{array}$}} & \multicolumn{12}{|c|}{$\begin{array}{l}\text { Females Inability to Develop Well the Mentioned Personality } \\
\text { Characteristics because of the Deficient Feminine Nature }\end{array}$} \\
\hline & & & & & & & & & & \multicolumn{4}{|c|}{$\begin{array}{l}\text { Females cannot develop } \\
\text { sociability skills well }\end{array}$} & \multicolumn{4}{|c|}{$\begin{array}{l}\text { Females cannot become } \\
\text { strong psychologically }\end{array}$} & \multicolumn{4}{|c|}{\begin{tabular}{|l|} 
Females cannot \\
become as strong as \\
men emotionally
\end{tabular}} \\
\hline & & $\stackrel{0}{\nu}$ & z & 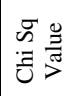 & 苟 & $\stackrel{0}{\nu}$ & z & 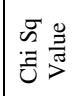 & $\frac{\mathscr{J}}{\frac{\Xi}{\pi}}$ & $\stackrel{0}{\nu}$ & z & 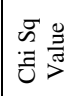 & $\frac{\mathscr{9}}{\frac{\pi}{\pi}}$ & $\stackrel{0}{\infty}$ & 之 & 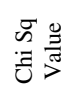 & $\frac{\mathscr{2}}{\frac{\pi}{\pi}}$ & $\stackrel{\tilde{\nu}}{\tilde{\nu}}$ & 之 & 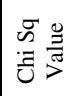 & $\frac{\stackrel{9}{ٍ}}{2}$ \\
\hline Rural & 300 & 243 & 57 & 114.08 & 0 & 66 & 234 & 92.96 & 0 & 241 & 59 & 109.20 & 0 & 234 & 66 & 92.96 & 0 & 240 & 60 & 106.80 & 0 \\
\hline Percentage & 50 & 40.5 & 9.5 & & & 11 & 39 & & & 40.2 & 9.8 & & & 39 & 11 & & & 40 & 10 & & \\
\hline Urban & 300 & 259 & 41 & \begin{tabular}{|l|}
156.96 \\
\end{tabular} & 0 & 55 & 245 & 119.07 & 0 & 257 & 43 & 151.23 & 0 & 256 & 46 & \begin{tabular}{|l|}
144.64 \\
\end{tabular} & 0 & 254 & 46 & 142.83 & 0 \\
\hline Percentage & 50 & 43.2 & 6.8 & & & 9.2 & 40.8 & & & 42.8 & 7.2 & & & 42.7 & 7.3 & & & 42.3 & 7.7 & & \\
\hline Total & 600 & 502 & 98 & 270.68 & 0 & 121 & 479 & 212.42 & 0 & 498 & 102 & 260.04 & 0 & 490 & 110 & 239.40 & 0 & 494 & 106 & 249.62 & 0 \\
\hline Percentage & 100 & 83.7 & 16.3 & & & 20.2 & 79.8 & & & 83 & 17 & & & 81.7 & 18.3 & & & 82.3 & 17.7 & & \\
\hline Z Value & & -1.77 & & & & 1.12 & & & & \begin{tabular}{|l|}
-1.74 \\
\end{tabular} & & & & -2.32 & & & & \begin{tabular}{|l|}
-1.49 \\
\end{tabular} & & & \\
\hline P Value & & .077 & & & & .263 & & & & .082 & & & & .020 & & & & .136 & & & \\
\hline
\end{tabular}

Dr. Mamoon Khan Khattak is Assistant Professor \& Incharge in the Department of Social Work \& Sociology, Kohat University of Science \& Technology (KUST), Kohat, Pakistan.

Dr. Khanzadi Fatima Khattak is Dean, Faculty of Sciences, Abdul Wali Khan University, Mardan, Pakistan.

Ms. Zubaida Khatoon Khattak is Ph.D Scholar in the Department of Economics, University of Peshawar, Peshawar, Pakistan. 